\title{
Nutrient controls of planktonic cyanobacteria biomass in coastal stormwater detention ponds
}

\author{
Amy Siegel ${ }^{1}$, Bridget Cotti-Rausch ${ }^{1}$, Dianne I. Greenfield ${ }^{1,2,4}$, James L. Pinckney $^{1,3, *}$ \\ ${ }^{1}$ Marine Science Program, ${ }^{2}$ Belle W. Baruch Institute for Marine and Coastal Sciences, \\ and ${ }^{3}$ Department of Biological Sciences, University of South Carolina, Columbia, South Carolina 29208, USA \\ ${ }^{4}$ Marine Resources Research Institute, 217 Fort Johnson Road, Charleston, South Carolina 29412, USA
}

\begin{abstract}
Stormwater detention ponds are a common best management practice (BMP) designed to moderate the impacts of development on surrounding ecosystems. On Kiawah Island, South Carolina, stormwater detention ponds receive high levels of nitrogen $(\mathrm{N})$ and phosphorus $(\mathrm{P})$ loading from non-point sources, which results in eutrophic conditions, recurrent water quality degradation, and problematic cyanobacterial blooms during summer and fall. The purpose of this study was to

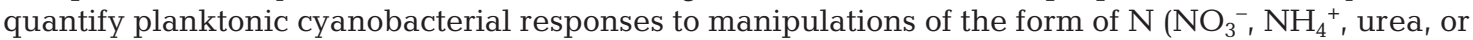
combinations) to determine their relative importance for cyanobacterial blooms. Nutrient addition bioassays were performed monthly (June to September 2009) in 2 brackish water ponds designated as K61 and K67. The 2 study sites were similar in all physical parameters except pond K61 was more brackish (salinity $=14 \pm 2$, mean $\pm \mathrm{SD}$ ) than pond K67 $(6 \pm 2)$. Urea additions resulted in a greater increase in cyanobacterial biomass than other $\mathrm{N}$ forms in pond $\mathrm{K} 61$ while urea and $\mathrm{NH}_{4}{ }^{+}$additions promoted growth in pond K67. The bioassays showed a relatively strong cyanobacteria response to the $\mathrm{N}$ additions for both ponds (except K67 in July). However, in all cases, the cyanobacterial contribution was always $<36 \%$ of total phytoplankton biomass. Our results suggest that both $\mathrm{NH}_{4}{ }^{+}$and urea may preferentially stimulate cyanobacterial growth in brackish stormwater detention ponds on Kiawah Island in the summer months. Although fertilizer application procedures and rates are not known for the areas drained by the stormwater detention ponds on Kiawah Island, our results suggest that the use of urea-based fertilizers, which produce both urea and $\mathrm{NH}_{4}{ }^{+}$in runoff, could foster the development and maintenance of cyanobacteria blooms.
\end{abstract}

KEY WORDS: Photopigment · Bioassay · Nutrient · Eutrophication · HPLC · Urea · Ammonium • Nitrate $\cdot$ ChemTax

Resale or republication not permitted without written consent of the publisher

\section{INTRODUCTION}

Anthropogenic nutrient inputs are of global concern because of their role in eutrophication (Nixon 1995). These inputs may stimulate primary production and promote the formation of harmful algal blooms (HABs) in environmentally-sensitive coastal regions (Paerl 1997, Bricker et al. 1999, Anderson et al. 2002, 2008). Human population growth is positively correlated with nutrient inputs, especially excess nitrogen $(\mathrm{N})$, which is typically the limiting nutrient in estuarine systems (Ryther \& Dunstan 1971, Nixon 1995, Mallin et al.
2004). Alterations of the landscape due to development on barrier islands has led to the creation of low-flow, shallow lagoons and increased non-point sources of pollution (Aelion et al. 1997, Mallin \& Wheeler 2000, Tufford et al. 2003). Furthermore, landscape alterations and human habitation frequently result in significant application of chemicals (fertilizers, herbicides, pesticides, etc.) and daily irrigation to maintain open green spaces. Current estimates indicate that approximately half the fertilizer applied to golf courses is transported directly into water bodies or leaches into groundwater (Nosengo 2003). Furthermore, Mallin \& 
Wheeler (2000) determined that nitrate concentrations were greater in streams leaving golf courses than those entering and runoff generated by golf courses had sufficient nitrate concentrations to contribute to the eutrophication of the surrounding estuarine, salt marsh, and tidal creek ecosystems.

In a 5 yr period (1994 to 1999) the number of stormwater detention ponds in coastal South Carolina increased by $70 \%$ (from 1174 to 1997 ponds) and areal coverage was increased by 3300 ha (Brock 2006). Golf course and residential development, including the construction of multiple stormwater detention ponds as catchments for runoff, has been particularly intense on Kiawah Island. Prior to development in the 1970s, there were 15 natural ponds on Kiawah Island while currently there are 136 ponds that cover 136 ha, accounting for $8.4 \%$ of the total land area on the island (Lewitus et al. 2003, 2008, N. Shea pers. comm.). Over $95 \%$ of the ponds on Kiawah Island are brackish to marine with low flushing rates that create ideal conditions for phytoplankton growth (Lewitus et al. 2003, 2008, Brock 2006). High levels of N and phosphorus (P) loading from golf course, road, and residential runoff have been implicated as the causative agents of eutrophication in these ponds (Lewitus et al. 2008). Previous work has demonstrated that phytoplankton productivity and growth in the pond network on Kiawah Island is usually limited by dissolved inorganic N (Lewitus et al. 2003, 2008, Bunker 2004, Drescher 2005, Brock 2006), making this system responsive to $\mathrm{N}$ inputs.

The South Carolina Algal Ecology Laboratory (SCAEL), jointly operated by the University of South Carolina and the South Carolina Department of Natural Resources, has conducted routine monitoring and research at Kiawah Island since 2001. These efforts have revealed that Kiawah Island detention ponds are 'hot spots' for harmful algal blooms (HABs) spanning a wide range of phytoplankton taxa, including dinoflagellates, raphidophytes, and cyanobacteria (e.g. Lewitus et al. 2003, 2004, 2008, Lewitus \& Holland 2003, Keppler et al. 2006). Cyanobacteria blooms are particularly persistent in Kiawah Island ponds (Brock 2006, Lewitus et al. 2008), and the most commonly observed genera from 2001 to 2005 were Oscillatoria, Anabaena, and Microcystis (Lewitus et al. 2008). These same genera continue to be abundant in low to mid-salinity ponds (D. I. Greenfield unpubl.). For example, Kiawah Island pond number 67 (henceforth 'K67', and similar notation hereafter), has experienced recurrent blooms of Microcystis aeruginosa, including a dense bloom from September 2004 to January 2005. During this bloom, maximum cell densities reached $9.1 \times 10^{5}$ cells $\mathrm{ml}^{-1}$ and levels of the hepatotoxin microcystin were reportedly $>11000 \mathrm{ppb}$, a level that far exceeds the
World Health Organization threshold for microcystin (1 ppb) (Brock 2006). While levels of dissolved organic nitrogen (DON) were not reported for this study, dissolved inorganic nitrogen (DIN) levels were as follows. Ammonium was typically $<5 \mu \mathrm{M}$ with 2 drastic increases of 27 and $37 \mu \mathrm{M}$ occurring on 10 and 22 September 2004, respectively, and nitrate + nitrite levels fluctuated between 1 and $17 \mu \mathrm{M}$ throughout the duration of the bloom, compared to dissolved inorganic phosphorus (DIP), as orthosphosphate, being $>200 \mu \mathrm{M}$ during that same time interval (SCAEL unpubl.). In fact, multiple studies have shown that DIN levels at Kiawah Island are typically low $(<1)$ relative to DIP (e.g. Lewitus et al. 2003, 2008, Brock 2006), suggesting that Kiawah Island phytoplankton may be N-limited.

Reviews of the SCAEL archives revealed that DON levels may be elevated relative to DIN in select ponds (Lewitus et al. 2003, 2004, 2008), including pond K67, one of the sites considered here (Lewitus et al. 2003). Recent studies support this observation (D. I. Greenfield unpubl.). Growth of raphidophytes and dinoflagellates responded to both DIN and DON additions at pond K2 (Hayes and Lewitus 2005), and elevated DON levels have been associated with raphidophyte blooms in SC detention ponds, including those at Kiawah (Lewitus et al. 2004). Furthermore, while urea has not been routinely monitored at Kiawah, evidence suggests that that urea may be an important component of the DON pool in select ponds (SCAEL unpubl.). These findings imply that although Kiawah Island ponds may be limited with respect to DIN, they could be rich in DON.

Several studies have investigated the impacts of dissolved inorganic nitrogen (DIN) additions on cyanobacterial growth and toxin production (Codd \& Poon 1988, Sivonen 1990, Kameyama et al. 2002, Vezie et al. 2002, Downing et al. 2005, Moisander et al. 2009). The importance of DON as a source of $\mathrm{N}$ for cyanobacteria has been well-documented (Berman 1997, 2001, Berg et al. 2001, 2003, Glibert et al. 2004, Bradley et al. 2010). However, limited information exists on cyanobacterial responses when both inorganic and organic $\mathrm{N}$ forms are present and available for use. Although little is known about uptake mechanisms, some forms of DON may be used by phytoplankton as a source of N for growth (Antia et al. 1991, Bronk \& Glibert 1993, Finlay et al. 2010). For example, once taken up by the cell, urea is converted to $\mathrm{NH}_{4}{ }^{+}$by urease or urea amidolyase. Like $\mathrm{NO}_{3}{ }^{-}$assimilation, urea uptake is usually higher in the light and may be inhibited by $\mathrm{NH}_{4}{ }^{+}$(Vincent 1992). When $\mathrm{N}$ is the limiting nutrient, the form of $\mathrm{N}$ (e.g. $\left.\mathrm{NO}_{3}{ }^{-}, \mathrm{NH}_{4}{ }^{+}, \mathrm{DON}\right)$ available for uptake may influence phytoplankton community composition due to species-specific differences in uptake rates. Intrinsic differences in uptake abilities between different 
phytoplankton species may result in dominance by specific species or groups of phytoplankton in response to different concentrations and forms of $\mathrm{N}$.

The aim of this study was to quantify the growth responses of planktonic cyanobacteria to the manipulation of forms of $\mathrm{N}\left(\mathrm{NO}_{3}{ }^{-}, \mathrm{NH}_{4}{ }^{+}, \mathrm{DON}\right.$ as urea, and combinations) to determine which form or combination of $\mathrm{N}$ additions stimulates the greatest cyanobacterial growth in Kiawah Island stormwater detention ponds. The primary hypothesis, based on the energetic requirements for $\mathrm{N}$ uptake (Flores \& Herrero 2005, Finlay et al. 2010), was that $\mathrm{N}$ preference as indicated by an increase in cyanobacteria biomass should be $\mathrm{NH}_{4}{ }^{+}>$urea $>\mathrm{NO}_{3}{ }^{-}$. The goal of this project was to provide insights into relationships between nutrient loading and cyanobacterial growth for developing effective preventative measures to mitigate bloom formation.

\section{MATERIALS AND METHODS}

Study site. Kiawah Island, a depositional barrier island located $54 \mathrm{~km}$ south of Charleston, South Carolina $\left(32.606^{\circ} \mathrm{N}, 80.094^{\circ} \mathrm{W}\right)$, is ca. $16 \mathrm{~km}$ long and $2.7 \mathrm{~km}$ wide at its widest point and has a total area of $29.0 \mathrm{~km}^{2}$. Two ponds were selected due to a history of water quality problems, harmful algal blooms (Shea 2001, Brock 2006, Lewitus et al. 2008), and similarity in size and volume. Pond K61 $\left(32.6170^{\circ} \mathrm{N}, 80.06771^{\circ} \mathrm{W}\right)$ and pond $\mathrm{K} 67\left(32.6185^{\circ} \mathrm{N}, 80.0605^{\circ} \mathrm{W}\right)$ are shallow ponds (mean depth $=1.7 \mathrm{~m}$ ) on the eastern portion of the island (Brock 2006). Pond K61 has an area of $0.012 \mathrm{~km}^{2}$, is isolated from the main pond network but connected to the saltmarsh via pond K56 and surrounded by residential developments with little bank vegetation. Pond K67, with an area of $0.009 \mathrm{~km}^{2}$, is the terminal (upstream) pond in a 3 pond system (K73, K63, and K67). Terminal ponds are the last ponds to receive water during flood tide and often have recurring water quality problems. Pond K67 is surrounded by a vegetated buffer zone, residential developments, and roadway, and it receives water from 4 stormwater pipes: one that drains the golf course and 3 that drain residential communities (Shea 2001, Brock 2006). Pond K67 was also the subject of a constructed wetland modeling effort to reduce nutrient influx as a HAB mitigation strategy (Bunker 2004, Brock 2006, Drescher et al. 2006, Strosnider et al. 2007, Lewitus et al. 2008). Information on application procedures, timing, and fertilizer compounds applied on Kiawah Island were proprietary and therefore not available for examination.

Experimental design. Bioassays were conducted in both K61 and K67 monthly from June to September
2009. Incubation water was collected at the surface in quadruplicate using acid-washed wide-mouthed 2.51 Nalgene polycarbonate carboys, and one 11 sample was collected for measurements of the initial pond parameters (nutrients, temperature, salinity, and $\mathrm{pH}$ ). Nutrients were added to the carboys to produce the following treatments: (1) control (no nutrient additions), (2) $\mathrm{NO}_{3}{ }^{-}$, (3) $\mathrm{NH}_{4}{ }^{+}$, (4) urea, (5) $\mathrm{NO}_{3}{ }^{-}+\mathrm{NH}_{4}{ }^{+}$, (6) $\mathrm{NO}_{3}{ }^{-}+$ urea, (7) $\mathrm{NH}_{4}{ }^{+}+$urea, and (8) phosphate $\left(\mathrm{PO}_{4}{ }^{3-}\right)$. N was added in equimolar concentrations $(20 \mu \mathrm{M}, \mathrm{N}$ final concentration) as urea and $\mathrm{KNO}_{3}$ or $\left(\mathrm{NH}_{4}\right)_{2} \mathrm{SO}_{4}$ for $\mathrm{NO}_{3}{ }^{-}$and $\mathrm{NH}_{4}{ }^{+}$respectively. All $\mathrm{N}$ treatments were supplemented with $10 \mu \mathrm{M}$ (final concentration) phosphate, added as $\mathrm{KH}_{2} \mathrm{PO}_{4}$, to ensure that $\mathrm{P}$ was not limiting for the $\mathrm{N}$ treatments. The carboys were submerged in the pond and incubated for $48 \mathrm{~h}$ in a nylon mesh bag lined with fiberglass neutral density screen to reduce ambient irradiance by $40 \%$ to a saturating irradiance of 300-700 $\mu \mathrm{mol}$ quanta $\mathrm{m}^{-2} \mathrm{~s}^{-1}$. Subsamples for nutrient measurements, microscopy, and photopigment analysis were taken initially and at 24 and $48 \mathrm{~h}$ in $500 \mathrm{ml}$ opaque Nalgene bottles. Samples were kept in the dark at ambient temperature and processed within $4 \mathrm{~h}$ of collection.

Water chemistry. Water samples were pooled from all 4 replicates then filtered through sterile $0.45 \mu \mathrm{m}$ pore size cellulose acetate membrane syringe filters and immediately frozen for later analysis. The concentration of dissolved nutrients $\left(\mathrm{NO}_{3}{ }^{-}, \mathrm{NH}_{4}{ }^{+}\right.$, and $\left.\mathrm{PO}_{4}{ }^{3-}\right)$ was determined using a Lachat Quickchem 8500T autoanalyzer according to the wet chemical methods of Grasshoff et al. (1983), Johnson \& Petty (1983), and Zimmerman \& Keefe (1991). Salinity, which was measured with a refractometer in units of $\mathrm{psu}$, and $\mathrm{pH}$ were measured at the beginning of each bioassay.

Microscopy. One $20 \mathrm{ml}$ aliquot of the incubation water was taken for microscopic analysis for each treatment at 24 and $48 \mathrm{~h}$ (pooled from 4 replicates). Samples were immediately preserved with $2 \mathrm{ml}$ Lugol's solution and stored in the dark at room temperature. Cells were identified to the genus level and abundances were estimated using the standard counting chamber method (Utermöhl 1958). Ten $\mathrm{ml}$ of water were settled for a minimum of $18 \mathrm{~h}$ and enumerated using an Olympus IMT-2 microscope at 150× magnification.

Photopigment measurements. Phytoplankton community composition was determined based on biomarker photopigment concentrations (Millie et al. 1993, Jeffrey et al. 1997, Wright \& Jeffrey 2006). Aliquots $(50-150 \mathrm{ml})$ of the incubation water were filtered under a gentle vacuum $(<50 \mathrm{KPa})$ through a glass fiber filter ( $25 \mathrm{~mm}$ diameter; Whatman GF/F), immediately frozen, and stored at $-80^{\circ} \mathrm{C}$. Filters were lyophilized for 18 to $24 \mathrm{~h}$ at $-50^{\circ} \mathrm{C}$. Photopigments 
were extracted by adding $750 \mu \mathrm{l}$ of $90 \%$ aqueous acetone solvent followed by storage for 12 to $20 \mathrm{~h}$ at $-20^{\circ} \mathrm{C}$. Filtered extracts $(250 \mu \mathrm{l})$ were injected into a Shimadzu HPLC with a single monomeric column (Rainin Microsorb, $0.46 \times 1.5 \mathrm{~cm}, 3 \mu \mathrm{m}$ packing) and a polymeric (Vydac 201TP54, $0.46 \times 25 \mathrm{~cm}, 5 \mu \mathrm{m}$ packing) reverse-phase $\mathrm{C}_{18}$ column in series. A non-linear binary gradient consisting of solvent A (methanol: $0.5 \mathrm{M}$ ammonium acetate, 4:1) and solvent B (methanol: acetone, 4:1) was used for the mobile phase (Pinckney et al. 1996). Absorption spectra and chromatograms $(440 \pm 4 \mathrm{~nm})$ were obtained using a Shimadzu SPDM10av photodiode array detector, and pigment peaks were identified by comparing retention times and absorption spectra with pure standards (DHI). The synthetic carotenoid $\beta$-apo-8'-carotenal (Sigma) was used as an internal standard. Pigment concentrations were analyzed using ChemTax to determine the relative abundance of major phytoplankton groups (Mackey et al. 1997, Pinckney et al. 2001, Lewitus et al. 2005). The initial pigment ratio matrix used for this analysis was derived from Lewitus et al. (2005), which was based on empirically measured pigment ratios for estuarine phytoplankton. The convergence procedure outlined by Latasa (2007) was used to minimize errors in algal group biomass due to inaccurate pigment ratio seed values.

Statistics. Differences in cyanobacterial biomass (chl $a_{\text {cyano }}$ ) and phytoplankton biomass (chl $\left.a_{\text {total }}\right)$ between treatments were determined using a repeated measures, randomized complete block design analysis of variance (ANOVA) with treatment as the main factor and date as the blocking factor. The repeated measures were pigment concentrations at 24 and $48 \mathrm{~h}$. The variables chl $a_{\text {cyano }}$ and chl $a_{\text {total }}$ violated the normality assumption and transformations to achieve normality were unsuccessful. However, ANOVA is robust with respect to small departures from normality (Sokal \& Rohlf 1981). Homogeneity of variances was checked using a Levene's test. A posteriori differences between treatment means were determined using the RyanEinot-Gabriel-Welsch F-test (REGW-F). A multivariate analysis of variance (MANOVA), with nutrient treatment as the main factor and individual cyanobacterial taxa as the variables for each pond at the 2 time intervals (4 separate analyses), was used to test for significant differences in cyanobacterial community composition. SPSS version 17.0 (IBM) was used for statistical tests, and the critical value for hypothesis testing was set at $\mathrm{p} \leq 0.01$ unless otherwise stated.


ChemTax cyanobacteria biomass $\left(\mu \mathrm{chl} \mathrm{a}^{-1}\right)$

Fig. 1. Relationships between ChemTax-derived estimates of cyanobacterial biomass and paired (a) cyanobacteria cell counts ( $\mathrm{n}=39$, adj $\mathrm{r}^{2}=0.47, \mathrm{p}<0.001$ ) and (b) zeaxanthin concentrations $\left(\mathrm{n}=629\right.$, adj $\left.\mathrm{r}^{2}=0.92, \mathrm{p}<0.001\right)$. Zeaxanthin is a primary accessory pigment for cyanobacteria

Table 1. Temperature, $\mathrm{pH}$, salinity, and nutrient concentrations for ponds K61 and K67. DIN: total dissolved inorganic nitrogen; DIP: total dissolved inorganic phosphorus (orthophosphate)

\begin{tabular}{|c|c|c|c|c|c|c|c|c|c|}
\hline Pond & Date & $\begin{array}{c}\text { Temperature } \\
\left({ }^{\circ} \mathrm{C}\right)\end{array}$ & $\mathrm{pH}$ & $\begin{array}{l}\text { Salinity } \\
\text { (psu) }\end{array}$ & $\begin{array}{c}{\left[\mathrm{NO}_{3}^{-}+\mathrm{NO}_{2}^{-}\right]} \\
\left.(\mu \mathrm{mol} \mathrm{l})^{-1}\right)\end{array}$ & $\begin{array}{c}{\left[\mathrm{NH}_{4}^{+}\right]} \\
\left(\mu \mathrm{mol} \mathrm{l} l^{-1}\right)\end{array}$ & $\begin{array}{c}{[\mathrm{DIN}]} \\
\left(\mu \mathrm{mol} \mathrm{l^{-1 }}\right)\end{array}$ & $\begin{array}{c}{\left[\mathrm{PO}_{4}{ }^{3-}\right]} \\
\left(\mu \mathrm{mol} \mathrm{l} 1^{-1}\right)\end{array}$ & DIN:DIP \\
\hline \multirow[t]{4}{*}{ K61 } & 02 Jun 09 & 24.2 & 7.94 & 15 & 0.30 & 1.25 & 1.51 & 49.1 & 0.03 \\
\hline & $28 \mathrm{Jul} 09$ & 30.4 & 7.73 & 15 & 0.95 & 1.28 & 2.23 & 53.6 & 0.04 \\
\hline & 18 Aug 09 & 31.6 & 7.76 & 15 & 0.88 & 2.61 & 3.48 & 31.0 & 0.11 \\
\hline & 11 Sep 09 & 27.6 & 7.75 & 11 & 0.44 & 5.60 & 6.03 & 25.9 & 0.23 \\
\hline \multirow[t]{4}{*}{ K67 } & 02 Jun 09 & 22.9 & 8.13 & 5 & 1.10 & 7.78 & 8.86 & 84.0 & 0.11 \\
\hline & 28 Jul 09 & 29.8 & 7.91 & 9 & 0.64 & 2.69 & 3.33 & 17.2 & 0.19 \\
\hline & 18 Aug 09 & 30.8 & 8.17 & 5 & 2.76 & 11.56 & 14.33 & 93.0 & 0.15 \\
\hline & 11 Sep 09 & 26.1 & 7.76 & 5 & 1.46 & 8.64 & 10.09 & 74.3 & 0.14 \\
\hline
\end{tabular}




\section{RESULTS}

\section{Pond conditions}

The temperature during the summer of 2009 was $28^{\circ} \mathrm{C}$ \pm 3 (mean $\pm 1 \mathrm{SD}$ ) for both study sites while the average $\mathrm{pH}$ was $7.8 \pm 0.1$ for pond K61 and $8.0 \pm 0.2$ for pond K67 (Table 1). However, pond K61 had a higher average salinity $(14 \pm 2)$ than pond K67 (6 \pm 2$)$. For both ponds, high ambient $\mathrm{PO}_{4}{ }^{3-}$ concentrations $(53.3 \pm 26.3 \mu \mathrm{M})$ resulted in an average ratio of DIN to DIP after nutrient additions of 0.31 to 0.86 . Over the sampling period, DIN:DIP in the pond water and bioassays was considerably lower than the canonical Redfield ratio of 16:1.

The reliability of ChemTax-derived estimates for cyanobacterial biomass were assessed by comparing the estimates to cyanobacteria cell counts and zeaxanthin concentrations (Fig. 1). Paired samples for cell counts and HPLC pigment measurements were compared using linear regression analysis and showed reasonable agreement between the 2 methods $(n=39$, adj $\left.\mathrm{r}^{2}=0.47, \mathrm{p}<0.001\right)$. ChemTax cyanobacterial biomass was also highly correlated $\left(n=629\right.$, adj $r^{2}=0.92$, $p<$ 0.001 ) with concentrations of zeaxanthin, a marker pigment for cyanobacteria. Collectively, these results suggest that ChemTax provided reliable estimates of cyanobacterial biomass.

\section{Pond community composition}

The initial phytoplankton community composition was determined prior to each bioassay based on ChemTax-derived estimates of algal group biomass (Fig. 2). Diatoms, cyanobacteria, chlorophytes, euglenophytes, and prasinophytes were common in the ponds from June to September. A diatom bloom occurred in K67 in July while the August bloom in K61 was composed of diatoms, cyanobacteria, chlorophytes, and euglenophytes. Total phytoplankton biomass ( $\left.\mathrm{chl} a_{\text {total }}\right)$ in pond K61 steadily increased from $8.55 \pm 1.12 \mu \mathrm{g} \mathrm{l}^{-1}$ in June to a maximum value of $27.91 \pm$ $1.14 \mathrm{\mu g} \mathrm{l}^{-1}$ in September (Fig. 3). In pond K67 initial chl $a_{\text {total }}$ increased from $4.18 \pm 0.35 \mu g \mathrm{l}^{-1}$ in June to

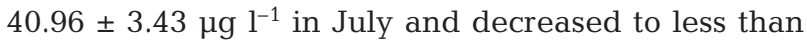
$10 \mu \mathrm{g} \mathrm{l}^{-1}$ for the remainder of the sampling period.

Initial cyanobacterial biomass ( $\mathrm{chl} a_{\text {cyano }}$ in pond $\mathrm{K} 61$ increased from a seasonal minimum of $0.53 \pm 0.08 \mu \mathrm{g}$ $\mathrm{l}^{-1}$ in June to a maximum of $7.58 \pm 1.23 \mu \mathrm{g} \mathrm{l}^{-1}$ in August before decreasing to $3.80 \pm 0.08 \mu \mathrm{g} \mathrm{l}^{-1}$ in September. In pond K61, cyanobacteria represented $6 \%$ of the chl $a_{\text {total }}$ in June and reached a maximum of $36 \%$ in July (Fig. 3). In pond K67, initial chl $a_{\text {cyano }}$ was $0.25 \pm$ $0.02 \mu \mathrm{g} \mathrm{l}^{-1}$ in June and reached a maximum of $2.60 \pm$ $0.77 \mathrm{\mu g} \mathrm{l}^{-1}$ in July before decreasing below $1.0 \mathrm{\mu g} \mathrm{l}^{-1}$ for duration of the sampling period. In pond K67 cyano-

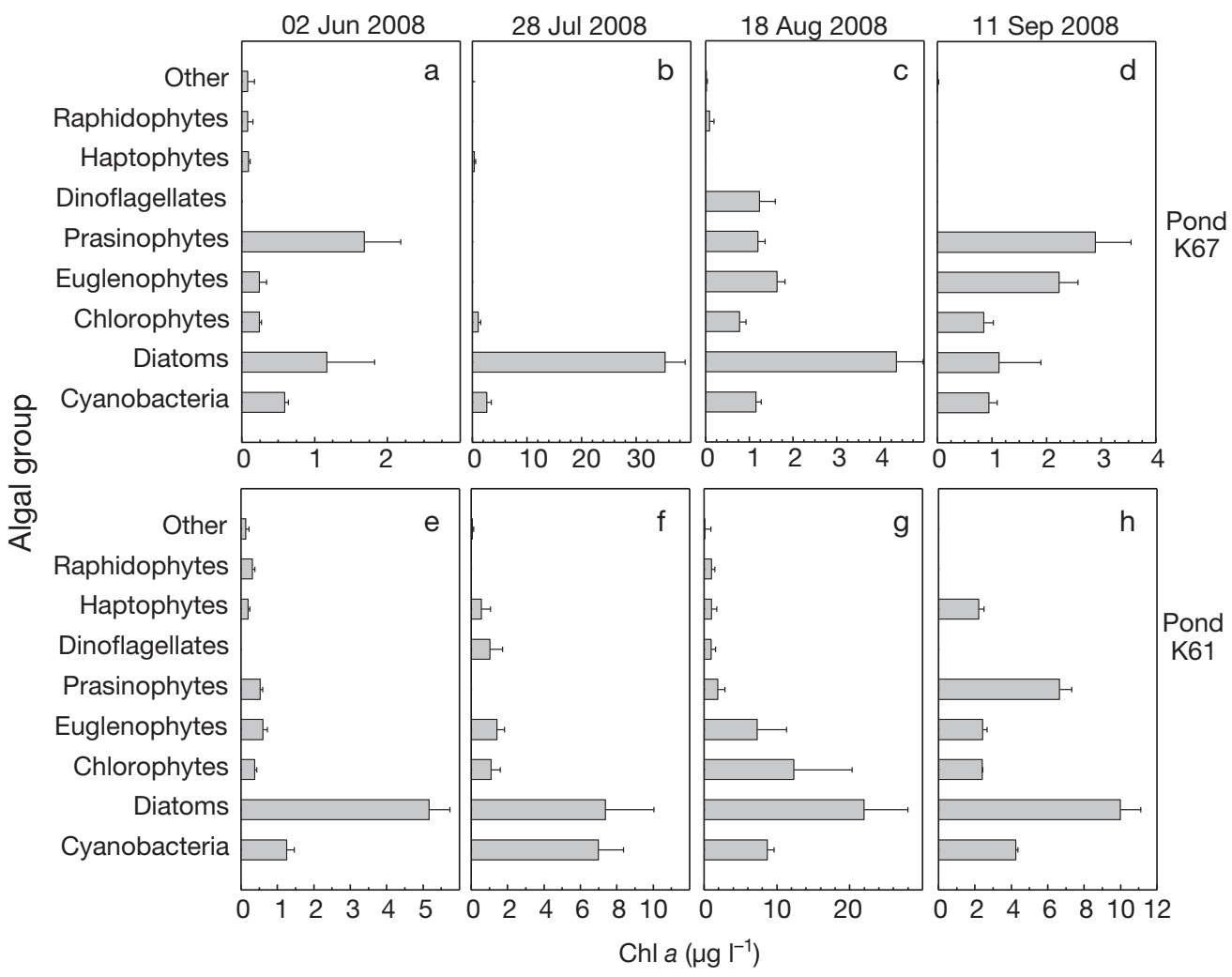

Fig. 2. ChemTax-derived phytoplankton community composition and algal group biomass (mean $+1 \mathrm{SD} ; \mathrm{n}=5)$ in ponds K67 $(\mathrm{a}-\mathrm{d})$ and $\mathrm{K} 61(\mathrm{e}-\mathrm{h})$ on the 4 sampling dates. Note the difference in $\mathrm{x}$-axis scales 


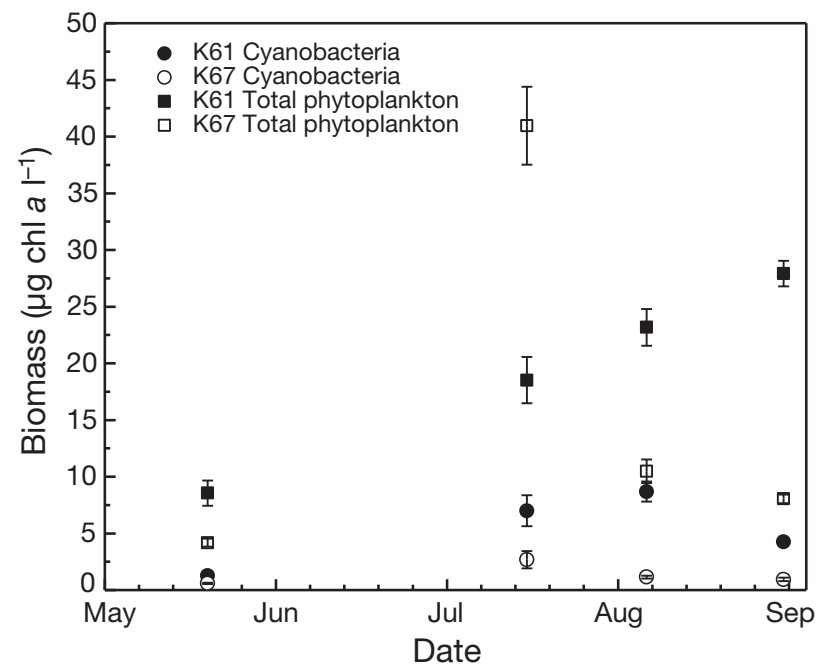

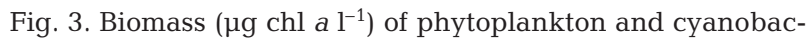
teria (mean $\pm \mathrm{SE}_{;} \mathrm{n}=5$ ) in ponds K61 and K67 at the initiation of the bioassays in June, July, August, and September 2009 bacteria accounted for less of the phytoplankton biomass, $\sim 6 \%$ in June and July and $~ 9 \%$ in August and September.

\section{NUTRIENT ADDITION BIOASSAYS}

Microscopic enumeration revealed differences in the initial abundances and responses of cyanobacteria taxa to the bioassay treatments (Figs. 4 \& 5). In general, all 4 genera (Microcystis, Aphanizomenon, Oscillatoria, and Anabaena) increased in abundance following nutrient additions in pond K61. In pond K67, Microcystis, Anabaena, and Oscillatoria increased with nutrient additions. Overall, the responses of species of these 4 genera were more consistent in pond K61. Four separate 2factor (date and nutrient treatment) MANOVAs were performed for the 2 time intervals ( 24 and $48 \mathrm{~h}$ ) at each pond and no significant nutrient effects on

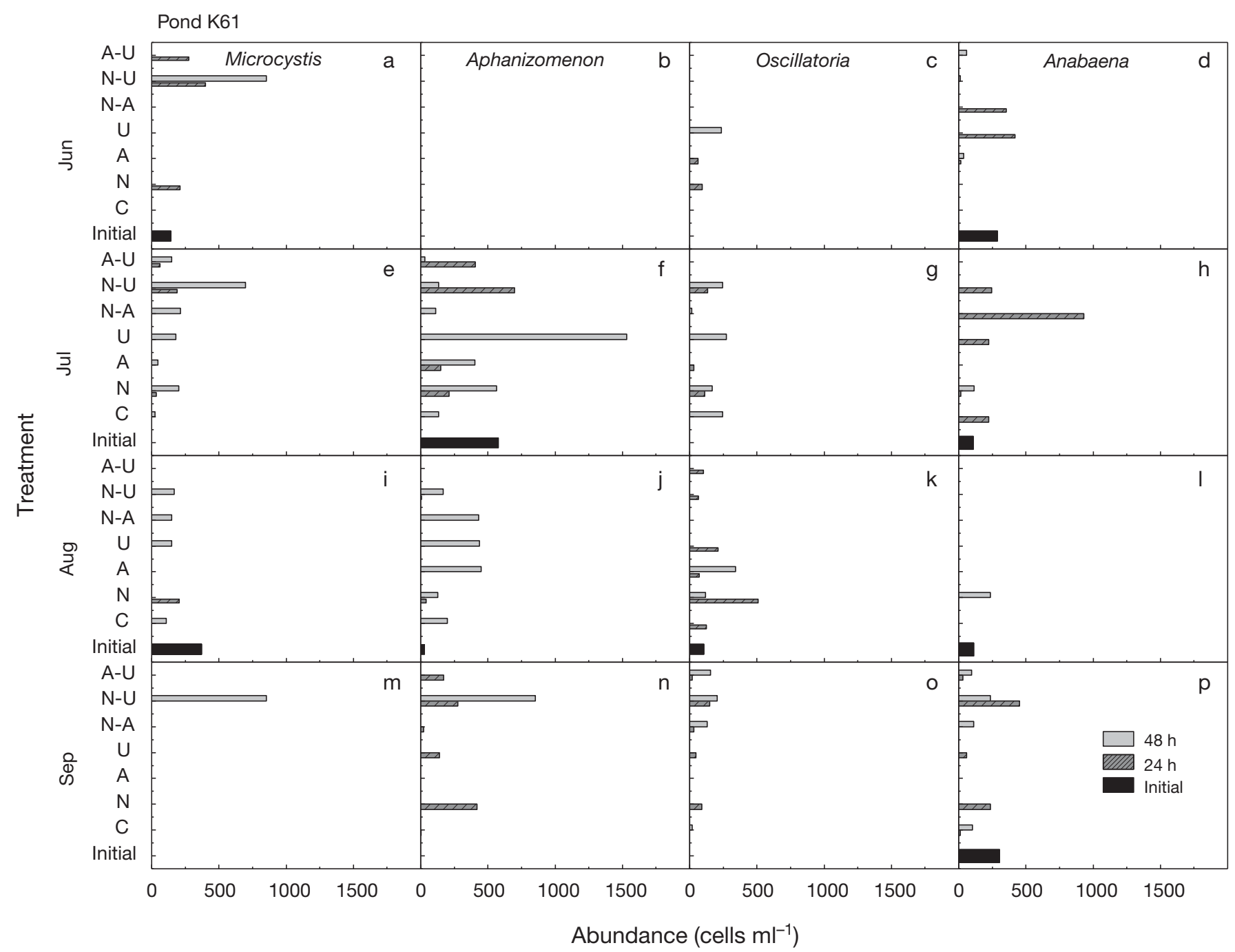

Fig. 4. Abundance of cells of the 4 most common cyanobacterial genera found in 4 bioassays in June (a-d), July (e-h), August (i-l), and September $(\mathrm{m}-\mathrm{p}) 2009$ in pond K61 at initiation and after 24 and $48 \mathrm{~h}$ of incubation. Treatment abbreviations are defined in Table 2. 


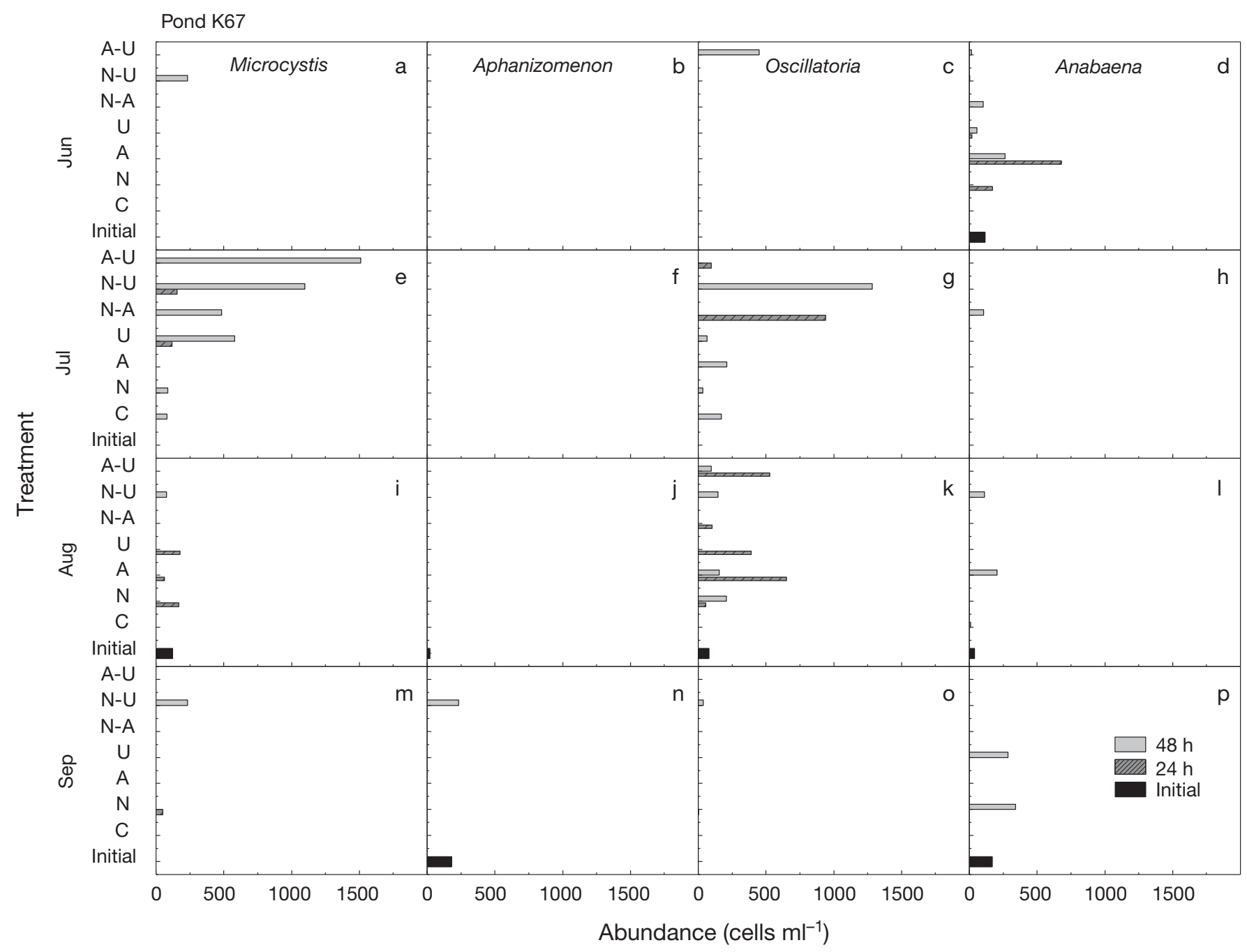

Fig. 5. Abundance of cells of the 4 most common cyanobacterial genera found in 4 bioassays in June (a-d), July (e-h), August $(\mathrm{i}-1)$, and September $(\mathrm{m}-\mathrm{p}) 2009$ in pond K67 at initiation and after 24 and $48 \mathrm{~h}$ of incubation. Treatment abbreviations are defined in Table 2

cyanobacterial community composition were detected ( $\mathrm{p}>0.15)$. The high variability in responses as well as low number of enumerated samples (64 total) likely contributed to the inability to detect significant differences.

The phytoplankton community (chl $a_{\text {total }}$ ) showed positive responses relative to the controls for all $\mathrm{N}$ additions in both ponds in all 4 bioassays. For pond K61, phytoplankton biomass increased by as much as $300 \%$ relative to the initial concentrations (Fig. 6A). Phytoplankton chl $a_{\text {total }}$ was as high as $500 \%$ after $48 \mathrm{~h}$ incubation in pond K67 (Fig. 6B). In both ponds, the responses to $\mathrm{P}$ additions were similar to the controls, indicating that $\mathrm{N}$ appeared to be the limiting nutrient for phytoplankton in these assays. The cyanobacterial community ( $\mathrm{chl} a_{\text {cyano }}$ ) exhibited similar responses to the nutrient additions. For pond K61, the largest responses occurred in June and July, followed by less of a response in August and a minimal increase in September (Fig. 6C). In pond K67, the June and August bioassays produced the largest increases in chl $a_{\text {cyano }}$ while much smaller responses were measured in July and September (Fig. 6D).

The relative responses of both total phytoplankton and cyanobacteria were further compared using linear regression analysis to discern differences between ponds and bioassays (Fig. 7). The greatest cyanobacterial response relative to total phytoplankton occurred in pond K61 in July and August (adj. $\mathrm{r}^{2}=0.89, F=$ 259.8, p < 0.001), as did a very small response in pond K67 in July. All other bioassays showed a moderate response with a near doubling in chl $a_{\text {cyano }}$ and a doubling in chl $a_{\text {total }}$ (adj. $\mathrm{r}^{2}=0.53, F=85.24, \mathrm{p}<0.001$ ). Collectively, these results suggest that $\mathrm{N}$ inputs to pond K61 in July and August may result in cyanobacterial blooms while $\mathrm{N}$ inputs at other times (June 
and September for K61; June to September for K67) do not seem to promote preferential cyanobacterial growth in either pond system.

The responses of both phytoplankton and cyanobacteria ( $\mathrm{chl} a_{\text {total }}$ and $\mathrm{chl} a_{\text {cyano }}$ ) to the individual nutrient additions for each bioassay were examined using 4 separate repeated measures ANOVAs to summarize the collective results of the bioassays (chl $a_{\text {total }}$ and chl $a_{\text {cyano }}$ for each pond) (Fig. 8). For chl $a_{\text {total }}$ in pond $\mathrm{K} 61$, there was a significant treatment effect $\left(F_{7,117}=\right.$ $9.69, \mathrm{p}<0.001$, power $=1.00$ ) as well as in pond K67 $\left(F_{7,117}=8.42, \mathrm{p}<0.001\right.$, power $\left.=1.00\right)$. The urea, $\mathrm{NO}_{3}{ }^{-}$, and $\mathrm{NH}_{4}{ }^{+}+$urea additions resulted in the highest increases in chl $a_{\text {total }}$ in pond K61 while there were no significant differences in chl $a_{\text {total }}$ for the $\mathrm{N}$ additions in pond K67 (Table 2). For cyanobacteria, the repeated
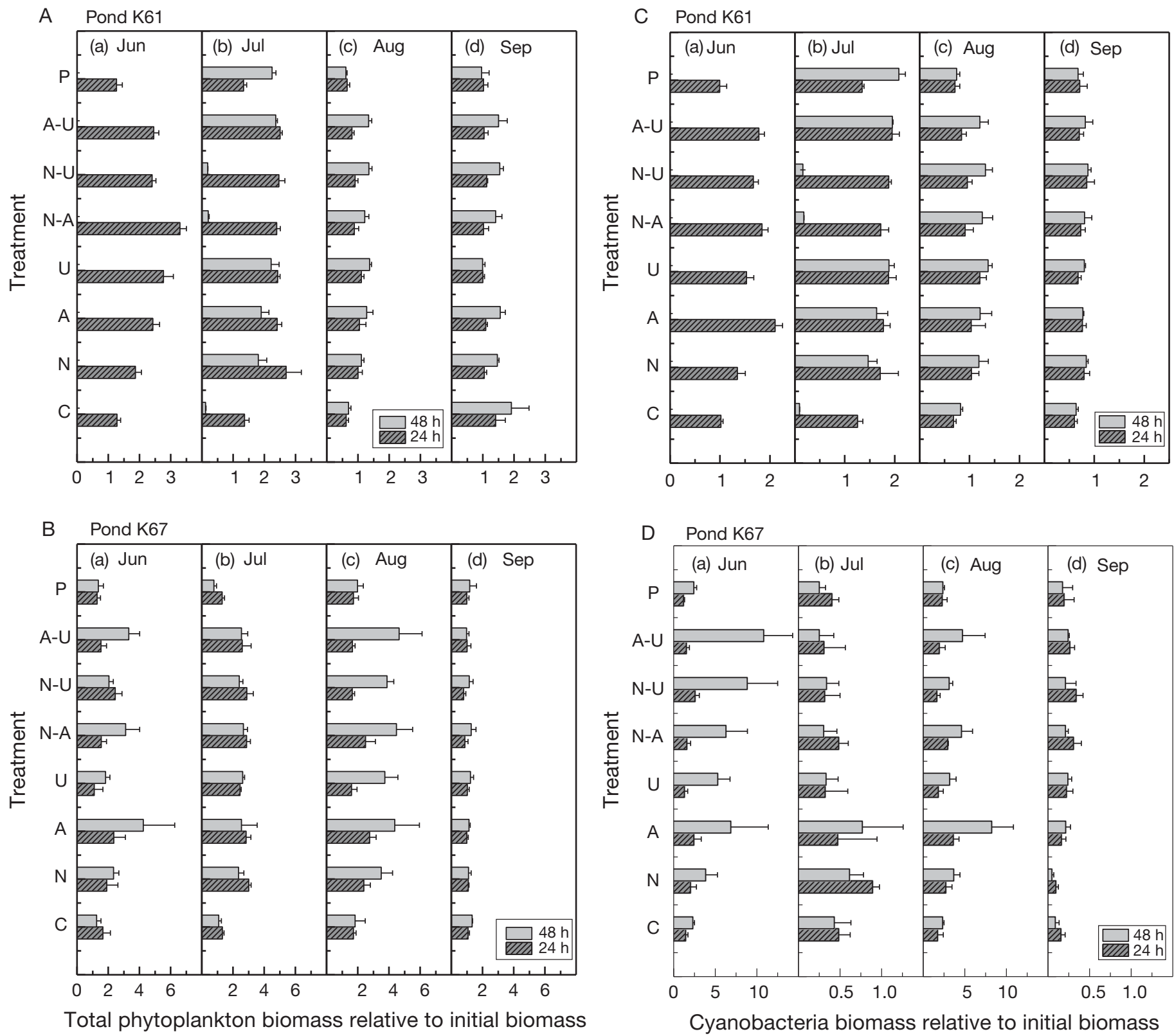

Total phytoplankton biomass relative to initial biomass

Fig. 6. (A) Phytoplankton responses and (C) cyanobacteria responses after 24 and $48 \mathrm{~h}$ to nutrient treatments for pond K61 for the 4 bioassays from (a) June (bioassay at $48 \mathrm{~h}$ was not available), (b) July, (c) August, and (d) September. (B) Phytoplankton responses and (D) cyanobacteria responses after 24 and $48 \mathrm{~h}$ to nutrient treatments for pond K67 for the 4 bioassays from (a) June, (b) July, (c) August, and (d) September. Values (mean $+1 \mathrm{SE} ; \mathrm{n}=5$ ) are expressed as a ratio relative to the initial abundance ( $\mu \mathrm{g} \mathrm{chl} \mathrm{a} \mathrm{l}^{-1}$ ) to normalize the data for direct comparisons of responses (treatment biomass/initial biomass). Treatment abbreviations are defined in Table 2 


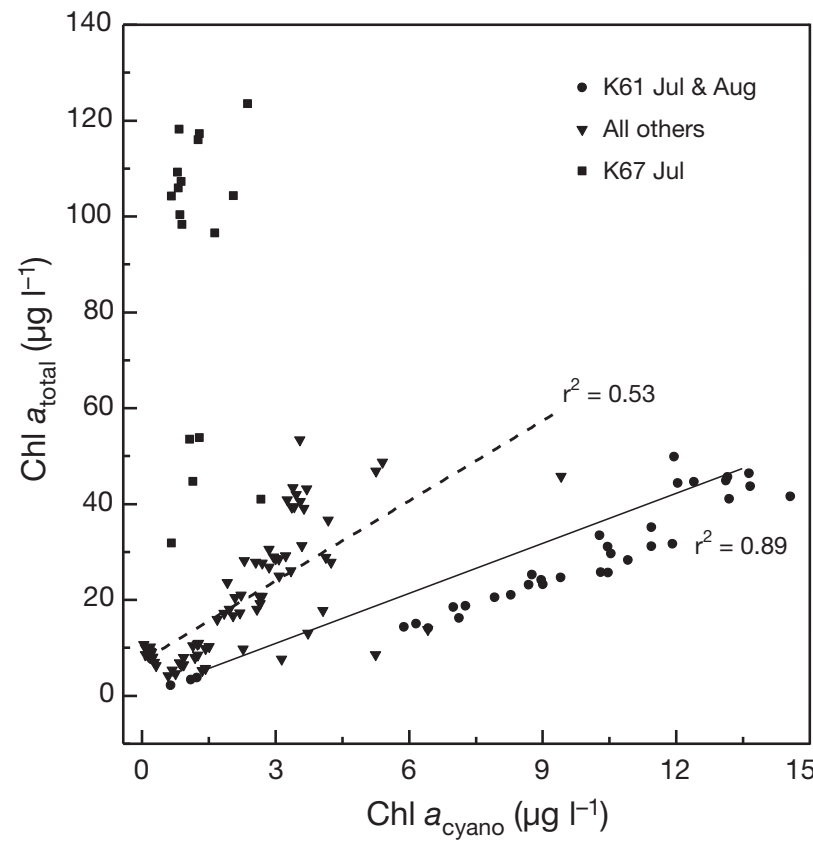

Fig. 7. Mean phytoplankton chl a vs. mean cyanobacteria chl $a(n=5$ replicates) for bioassay data. Regressions were performed for 3 separate subgroups to illustrate the strong cyanobacteria responses in July and August for pond K61 (solid line, $y=3.47 \mathrm{x}-4.88$, adj $\mathrm{r}^{2}=0.89$ ) and July for pond $\mathrm{K} 67$ (dashed line, $y=5.57 x+7.27$, adj $r^{2}=0.53$ ). The third group

(all others) did not exhibit a significant linear regression

measures ANOVAs detected significant treatment effects for both K61 $\left(F_{7,117}=5.11, \mathrm{p}<0.001\right.$, power $=$ $0.996)$ and $\operatorname{K} 67\left(F_{7,117}=5.47, \mathrm{p}<0.001\right.$, power $\left.=0.998\right)$. The urea additions produced significantly higher cyanobacterial biomass ( $\mathrm{chl} \mathrm{a}_{\text {cyano }}$ ) than all other treatments in pond $\mathrm{K} 61$ while the $\mathrm{NH}_{4}{ }^{+}+$urea and $\mathrm{NH}_{4}{ }^{+}$ yielded the highest $\mathrm{chl} \mathrm{a}_{\text {cyano }}$ in pond $\mathrm{K} 67$.

\section{DISCUSSION}

The aim of this study was to examine the relative stimulatory effects of different $\mathrm{N}$ sources on cyanobacterial growth in the stormwater detention ponds on a coastal barrier island in the southeastern USA. Blooms of cyanobacteria frequently occur in warm, stratified, eutrophic water bodies during the summer and early fall in temperate regions (Chorus \& Bartram 1999). However, a comprehensive mechanistic theory explaining the bloom dynamics of planktonic cyanobacteria is still incomplete (Hyenstrand et al. 1998). Increased availability of DIN is often associated with cyanobacterial growth (Vezie et al. 2002, Downing et al. 2005, Moisander et al. 2009, Davis et al. 2009), and blooms are also commonly associated with low inorganic N:P (Hyenstrand et al. 1998, Chorus \& Bartram

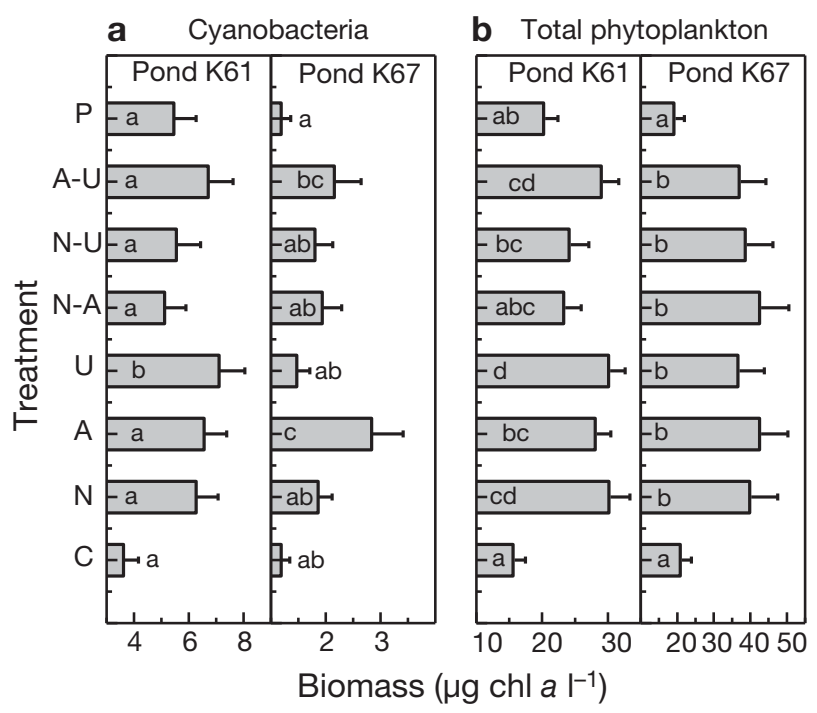

Fig. 8. Mean (+1 SE) biomass for each treatment and repeated measures ANOVA results for (a) cyanobacteria and (b) phytoplankton responses to the bioassays for each pond. The results of a posteriori multiple comparisons (REGW-F test) are indicated by lowercase letters inside each bar. Different letters indicate significance differences $(p<0.05)$. Treatment abbreviations are defined in Table 2

Table 2. Results of a posteriori comparisons of means for the different nutrient treatments (REGW- $F$ test, $p \leq 0.05$ ) for all bioassays combined. Groups are arranged from left to right according to their means in order of lowest to highest and those joined by a single underline were not significantly different. C: control; P: $\mathrm{PO}_{4}{ }^{3-} ; \mathrm{N}: \mathrm{NO}_{3}{ }^{-} ; \mathrm{A}: \mathrm{NH}_{4}{ }^{+} ; \mathrm{U}$ : urea; $\mathrm{A}-\mathrm{U}$ : $\mathrm{NH}_{4}{ }^{+}+$urea; $\mathrm{N}-\mathrm{A}: \mathrm{NO}_{3}{ }^{-}+\mathrm{NH}_{4}{ }^{+} ; \mathrm{N}-\mathrm{U}: \mathrm{NO}_{3}{ }^{-}+$urea

\begin{tabular}{|c|c|c|}
\hline Pond & Parameter & Homogeneous groups \\
\hline \multirow[t]{2}{*}{ K61 } & Cyanobacteria & $\begin{array}{lllllll}C & N-A & N-U & P & N & A & A-U \\
\end{array}$ \\
\hline & Total phytoplankton & 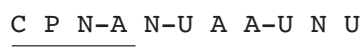 \\
\hline \multirow[t]{2}{*}{ K67 } & Cyanobacteria & $\underline{P} \subset \quad \mathrm{C} N-\mathrm{U} N \mathrm{~N}-\mathrm{A} A-\mathrm{A} \quad \mathrm{A}$ \\
\hline & Total phytoplankton & $P \quad C \quad U \quad A-U N-U N A \quad N-A$ \\
\hline
\end{tabular}

1999, Oliver \& Ganf 2000). The ability of cyanobacteria to exploit organic $\mathrm{N}$ has been previously demonstrated in both culture conditions and natural assemblages (Antia et al. 1975, Berman \& Bronk 2003, Bradley et al. 2010) so the likelihood that components of the DON pool in DON-enriched coastal ponds may serve as sources of $\mathrm{N}$ for cyanobacterial growth is high (Lewitus et al. 2003).

Temperature, $\mathrm{pH}$, and irradiance were comparable between the 2 study sites and within the optimum range for cyanobacterial growth (van der Westhuizen 
\& Eloff 1985, Codd \& Poon 1988, Rapala et al. 1997). Pond K61 was more brackish (salinity $=14$ ) than K67 (5) and the differences in salinity between the 2 ponds may be associated with the observed differences in cyanobacterial community responses. Microscopic enumerations revealed that the cyanobacterial community was composed of Microcystis, Anabaena, and Oscillatoria in pond K67 and Aphanizomenon, Anabaena, and Oscillatoria in pond K61. Aphanizomenon was common in K61 and detected in only one sample from K67. Monitoring of cyanobacteria in South Carolina lagoonal stormwater detention ponds from 2001 to 2005 established distinct salinity preferences for these taxa (Lewitus et al. 2008). Microcystis and Anabaena were most prevalent at low salinity ranges $(<10)$, while Oscillatoria is euryhaline with blooms documented at salinities as low as $<5$ and as high as 30. The observed salinity range during the study period was within the optimal range for Microcystis and Anabaena in pond K67 and may partly explain their observed abundance over the duration of the sampling period. Aphanizomenon, which was common in K61 and detected in only 1 sample (September 2009) from K67, tolerates salinity ranges of 0 to 30 , reaching maximum abundance at 10 (Lehtimäki 2000). The average salinity in pond K61 was within the tolerable salinity range for Aphanizomenon and only slightly above the optimal salinity.

The comparisons of ChemTax results with microscopic phytoplankton cell counts and zeaxanthin concentrations suggest that this approach provided reasonable estimates of cyanobacteria biomass. Although the ChemTax vs. cell counts comparison resulted in a low adjusted $r^{2}(0.47)$, much of the variation may be due to counting errors and the use of cell numbers instead of biovolume. Nonetheless, the bioassays were designed to test for responses relative to controls, and statistical comparisons assessed the magnitude of the responses rather than absolute biomass.

The bioassay results for brackish pond K61 did not support the hypothesis that $\mathrm{N}$ preference, as indicated by an increase in biomass, is $\mathrm{NH}_{4}{ }^{+}>$urea $>\mathrm{NO}_{3}{ }^{-}$. The urea treatment resulted in greater chl $a_{\text {cyano }}$ than other $\mathrm{N}$ forms and combinations in the bioassays. In a review of DON utilization by phytoplankton, Berman \& Bronk (2003) provide convincing evidence for the importance of urea as a $\mathrm{N}$ source for cyanobacteria in aquatic environments. Urea has previously been implicated as an important $\mathrm{N}$ source for several cyanobacterial taxa including both freshwater and marine strains of Synechococcus spp. (Berman \& Chava 1999; Sakamoto \& Bryant 2001; Solomon et al. 2010). Components of the DON pool (urea and amino acids) were used as the $\mathrm{N}$ source for a filamentous cyanobacterial bloom in the Baltic Sea (Berg et al. 2001, 2003) and an Aphani- zomenon ovalisporum bloom in Lake Kinneret, Israel (Berman 1997, 2001). Glibert et al. (2004) demonstrated a positive correlation between cyanobacterial biomass and urea uptake in Florida Bay. Bradley et al. (2010) found that as the DON:DIN ratio increases, there is an increasing utilization of DON as a primary $\mathrm{N}$ source. In the present study, the total phytoplankton community (chl $a_{\text {total }}$ ) did not exhibit any preference for $\mathrm{N}$ source and grew equally well on all $\mathrm{N}$ additions. Similar phytoplankton community responses to different forms of $\mathrm{N}$ have been reported for the Neuse River Estuary, North Carolina (Richardson et al. 2001). In contrast to pond K61, the cyanobacterial response in the lower salinity pond $\mathrm{K} 67$ was greater with $\mathrm{NH}_{4}{ }^{+}$ or $\mathrm{NH}_{4}{ }^{+}+$urea as the $\mathrm{N}$ source. In laboratory studies where both $\mathrm{NO}_{3}^{-}$and $\mathrm{NH}_{4}^{+}$are added in combination, $\mathrm{NH}_{4}{ }^{+}$was preferentially assimilated by cyanobacteria (Ohmori et al. 1977). The response of the total phytoplankton was similar to pond K61, with no demonstrated difference in stimulation by any of the $\mathrm{N}$ additions.

The collective results of the bioassays suggest that both cyanobacteria and the total phytoplankton community were N-limited in K61 and K67. Urea stimulated the greatest increase in cyanobacteria in the brackish pond $\mathrm{K} 61$ while $\mathrm{NH}_{4}{ }^{+}$or $\mathrm{NH}_{4}{ }^{+}+$urea were the preferred $\mathrm{N}$ sources in the low salinity pond K67. Furthermore, the different pair-wise combinations of $\mathrm{N}$ sources generally did not result in greater responses than the individual $\mathrm{N}$ additions. According to resource competition theory, $\mathrm{N}$-fixing algae should be relatively more abundant in aquatic environments when $\mathrm{N}$ is limiting (low N:P ratios) whereas non-diazotrophic phytoplankton (e.g. Microcystis) would be more abundant when N:P ratios are high (Tilman et al. 1982, 1986). Based on this theory, diazotrophic cyanobacteria (Aphanizomenon, Anabaena, and possibly Oscillatoria in this study) would be expected to be most abundant due to the low $\mathrm{N}: \mathrm{P}$ ratios observed in the bioassays. However, the addition of $\mathrm{PO}_{4}{ }^{3-}$ alone did not stimulate cyanobacteria biomass, indicating that nitrogen fixation by diazotrophs was not limited by P. Nutrient analyses of the pondwater and bioassays showed DIN:DIP ratios ranging from 0.86 to 0.03 , all much lower than the canonical 16 dictated by the Redfield ratio (Redfield et al. 1963). The extremely low N:P ratios should have favored diazotrophs, but the absence of a cyanobacterial response in the $\mathrm{P}$ only treatments in the bioassays suggests that diazotrophy alone may not explain the periodic cyanobacterial blooms in these ponds. Similarly, persistent and toxic blooms of the non-diazotroph Microcystis in pond K67 have been associated with DIN:DIP ratios of $<1$ (Brock 2006). Low N:P ratios have been correlated with diazotrophic cyanobacteria success in other systems 
(Smith 1983, Barcia 1994, Jacoby et al. 2000), and low DIN:DIP ratios are characteristic of the detention pond network on Kiawah Island overall (Lewitus et al. 2003, 2008, Brock 2006).

The bioassays showed a relatively strong cyanobacteria response to the $\mathrm{N}$ additions for both ponds, with the exception of the July bioassay in pond K67. However, in all cases, the cyanobacterial contribution was always $<36 \%$ of total phytoplankton biomass. Continued inputs of urea (pond K61) or $\mathrm{NH}_{4}^{+}$(pond K67) may have resulted in cyanobacterial 'blooms'. Our bioassays were limited to $48 \mathrm{~h}$, so the long-term (days to weeks) outcome of chronic $\mathrm{N}$ inputs cannot be determined with certainty.

The energetic requirements for $\mathrm{N}$ fixation are high due to the costs of maintaining specialized structures (heterocysts) and the enzyme nitrogenase (Turpin et al. 1985). The use of $\mathrm{NO}_{3}{ }^{-}$also has a relatively high energetic cost associated with light-dependent transporters and reductases to produce $\mathrm{NH}_{4}{ }^{+}$(Flores \& Herrero, 2005, Finlay et al. 2010). The acquisition of $\mathrm{NH}_{4}{ }^{+}$and urea is less energetically expensive in that these compounds can be acquired by light-independent diffusion or permeases as well as high-affinity, active membrane transporters (Solomon et al. 2010). Urea transporters used by cyanobacteria are distinct from eukaryotes, suggesting different enzyme kinetics and diverse metabolic pathways that may offer a competitive advantage under certain conditions for cyanobacteria (Solomon et al. 2010). Flores \& Herrero (2005) report that urea provides additional advantages in that $2 \mathrm{NH}_{4}{ }^{+}$ are produced for each molecule of urea imported and the $\mathrm{CO}_{2}$ released may provide a source of inorganic carbon for photosynthesis, especially at high $\mathrm{pH}$. Thus, under low-light, P-sufficient conditions, cyanobacteria growth using $\mathrm{NH}_{4}{ }^{+}$or urea may be favored (Finlay et al. 2010). Solomon et al. (2010) report that even at low ambient concentrations $(<1 \mu \mathrm{M} \mathrm{N})$, urea may provide as much as $50 \%$ of $\mathrm{N}$ required for growth by phytoplankton communities. Our experimental results are consistent with this energetic argument and suggest that both $\mathrm{NH}_{4}{ }^{+}$and urea may preferentially stimulate cyanobacterial growth in the stormwater detention ponds on Kiawah Island.

Stormwater detention ponds have become ubiquitous across coastal South Carolina including Kiawah Island. The molar ratio of DIN to DIP is typically $<1$ in these ponds, suggesting that phytoplankton biomass may be limited by N, and earlier studies have proposed management strategies targeting $\mathrm{N}$ (Lewitus et al. 2003, 2008, Brock 2006). The importance of $\mathrm{N}$ for cyanobacterial growth is a well documented phenomenon and the findings of this study confirm previous laboratory findings (Kameyama et al. 2002, Vezie et al. 2002). Our results suggest that management strategies aimed at lowering DIN inputs could result in decreased abundance of non-diazotrophic cyanobacteria as well as other phytoplankton. In addition, the current study provides new insight as to the potentially major role that urea plays in regulating cyanobacteria growth. Therefore, management strategies targeting organic nitrogen may be critical for mitigating cyanobacteria HABs in Kiawah Island ponds. Over $50 \%$ of the agricultural fertilizer worldwide is urea-based (Matthews 1994, Glibert et al. 2006) and its use is expected to double by 2050 (Millennium Ecosystem Assessment 2005). Although fertilizer application procedures are not known for the areas drained by the stormwater detention ponds on Kiawah Island, our results suggest that the use of urea-based fertilizers (which produce both urea and $\mathrm{NH}_{4}^{+}$) could foster the development and duration of cyanobacteria blooms in these ponds. However, the present study is limited to a single summer season and 2 ponds. Additional studies over several seasonal cycles and a variety of pond systems are necessary to evaluate the effects of the timing of nutrient inputs, changes in cyanobacterial assemblages, variations in the ratios of organic vs. inorganic nutrients, etc., on cyanobacterial bloom dynamics in these systems. All of these components are prerequisites for developing an effective nutrient management strategy for coastal lagoons.

Acknowledgements. We gratefully thank the Kiawah Island Community Association, particularly N. Shea, for permission to use their facilities to conduct this research. We also thank J. Taylor and R. Padgett for their help with the HPLC analysis, C. Keppler for assistance with the nutrient analysis, and E. Lawrenz, E. Goldman, K. DeMattio, S. Williams, L. Brock, and A. Douquette for help with field bioassays. T. Richardson provided invaluable editorial comments. This is publication no. 1629 from the Belle W. Baruch Institute for Marine and Coastal Sciences.

\section{LITERATURE CITED}

Aelion CM, Shaw JN, Wahl M (1997) Impact of suburbanization on ground water quality and denitrification in coastal aquifer sediments. J Exp Mar Biol Ecol 213:31-51

Anderson DM, Glibert PM, Burkholder JM (2002) Harmful algal blooms and eutrophication: nutrient sources, composition, and consequences. Estuaries 25:704-726

Anderson DM, Burkholder JM, Cochlan WP, Glibert PM and others (2008) Harmful algal blooms and eutrophication: examining linkages from selected coastal regions of the United States. Harmful Algae 8:39-53

Antia NJ, Berland BR, Bonin DJ, Maestrini SY (1975) Comparative evaluation of certain organic and inorganic sources of nitrogen for phototrophic growth of marine microalgae. J Mar Biol Assoc UK 55:519-539

Antia N, Harrison P, Oliveira L (1991) The role of dissolved organic nitrogen in phytoplankton nutrition, cell biology and ecology. Phycologia 30:1-89

Barcia J (1994) How to keep green algae in eutrophic lakes. Biologia 49:611-614 
Berg GM, Glibert PM, Jorgensen NOG, Balode M, Purina I (2001) Variability in inorganic and organic nitrogen uptake associated with riverine nutrient input in the Gulf of Riga, Baltic Sea. Estuaries 24:204-214

- Berg GM, Balode M, Purina I, Bekere S, Béchemin C, Maestrini SV (2003) Plankton community composition in relation to availability and uptake of oxidized and reduced nitrogen. Aquat Microb Ecol 30:263-274

- Berman T (1997) Dissolved organic nitrogen utilization by an Aphanizomenon bloom in Lake Kinneret. J Plankton Res 19:577-586

Berman T (2001) The role of DON and the effect of N:P ratios on occurrence of cyanobacterial blooms: implications from the outgrowth of Aphanizomenon in Lake Kinneret. Limnol Oceanogr 46:443-447

> Berman T, Bronk DA (2003) Dissolved organic nitrogen: a dynamic participant in aquatic ecosystems. Aquat Microb Ecol 31:279-305

Berman T, Chava S (1999) Algal growth on organic compounds as nitrogen sources. J Plankton Res 21:1423-1437

- Bradley PB, Lomas MW, Bronk DA (2010) Inorganic and organic nitrogen use by phytoplankton along Chesapeake Bay, measured using a flow cytometric sorting approach. Estuaries Coasts 33:971-984

Bricker SB, Clement CG, Pirialla DE, Orlando SP, Farrow DRG (1999) National estuarine eutrophication assessment: effects of nutrient enrichment in the nation's estuaries. National Oceanic and Atmospheric Administration, National Ocean Service, Special Projects Office and the National Centers for Coastal Ocean Science, Silver Spring, MD

Brock LM (2006) Water quality, nutrient dynamics, phytoplankton ecology and land uses within defined watersheds surrounding six detention ponds on Kiawah Island, South Carolina. MS thesis, College of Charleston, Charleston, SC

Bronk D, Glibert P (1993) Application of a ${ }^{15} \mathrm{~N}$ tracer method to the study of dissolved organic nitrogen uptake during spring and summer in Chesapeake Bay. Mar Biol 115: 501-508

Bunker K (2004) Hydrologic and nutrient analysis of pond K67 and K70 for constructed wetland project. MS thesis, College of Charleston, Charleston, SC

Chorus I, Bartram J (1999) Toxic cyanobacteria in water: a guide to their public health consequences, monitoring and management. World Health Organization, London

Codd GA, Poon GK (1988) Cyanobacterial toxins. In: Rogers LJ, Gallon JR (eds) Proc Phytochem Soc Eur, Vol 28. Oxford University Press, Oxford

Davis TW, Berry DL, Boyer GL, Gobler CJ (2009) The effects of temperature and nutrients on the growth and dynamics of toxic and non-toxic strains of Microcystis during cyanobacteria blooms. Harmful Algae 8:715-725

Downing TG, Meyer C, Gehringer MM, van de Venter M (2005) Microcystin content of Microcystis aeruginosa is modulated by nitrogen uptake rate relative to specific growth rate or carbon fixation rate. Environ Toxicol 20: 257-262

Drescher SR (2005) Capacity of nitrogen processing in watersheds surrounding detention ponds in Kiawah Island, SC. MS thesis, College of Charleston, Charleston, SC

Drescher SR, Burke MK, Lewitus AJ, Brown SD (2006) Background, short-term and potential long-term denitrification capacity of soils in urbanized coastal watersheds on Kiawah Island, South Carolina, USA. In: Williams T (ed) Proc Int Conf Hydrol Manage Forested Wetlands, no. 701PO406. American Society of Agricultural and Biological Engineers, St. Joesph, MI, p 167-194
Finlay K, Patoine A, Donald DB, Bogard MJ, Leavitt PR (2010) Experimental evidence that pollution with urea can degrade water quality in phosphorus-rich lakes of the Northern Great Plains. Limnol Oceanogr 55:1213-1230

Flores E, Herrero A (2005) Nitrogen assimilation and nitrogen control in cyanobacteria. Biochem Soc Trans 33:164-167

> Glibert PM, Heil CA, Hollander D, Revilla M, Hoare A, Alexander J, Murasko S (2004) Evidence for dissolved organic nitrogen and phosphorus uptake during a cyanobacterial bloom in Florida Bay. Mar Ecol Prog Ser 280: 73-83

Glibert PM, Harrison J, Heil C, Seitzinger S (2006) Escalating worldwide use of urea-a global change contributing to coastal eutrophication. Biogeochemistry 77:441-463

Grasshoff K, Ehrhardt M, Kremling K (1983) Methods of seawater analysis, 2nd edn. Verlag Chemie, Weinheim

Hayes KC, Lewitus AJ (2005) Bioassay nutrient responses of harmful algae in a South Carolina brackish lagoonal system. Am SocLimnol Oceanogr, Salt Lake City, UT

Hyenstrand P, Blomqvist P, Pettersson A (1998) Factors determining cyanobacterial success in aquatic systems - a literature review. Arch Hydrobiol Spec Issues Adv Limnol 51: 41-62

Jacoby JM, Collier DC, Welch EB, Hardy FJ, Crayton M (2000) Environmental factors associated with a toxic bloom of Microcystis aeruginosa. Can J Fish Aquat Sci 57: 231-240

Jeffrey SW, Mantoura RFC, Wright SW (1997) Phytoplankton pigments in oceanography: guidelines to modern methods. UNESCO, Paris

Johnson KS, Petty RL (1983) Determination of nitrate and nitrite in seawater by flow injection analysis. Limnol Oceanogr 28:1260-1265

Kameyama K, Sugiura N, Isoda H, Inamori Y, Maekawa T (2002) Effect of nitrate and phosphate concentration on production of microcystins by Microcystis viridis NIES 102. Aquat Ecosyst Health Manage 5:443-449

> Keppler CJ, Lewitus AJ, Ringwood AH, Hoguet J, Staton T (2006) Sublethal cellular effects of short-term raphidophyte and brevetoxin exposures on the eastern oyster Crassostrea virginica. Mar Ecol Prog Ser 312:141-147

- Latasa M (2007) Improving estimations of phytoplankton class abundances using CHEMTAX. Mar Ecol Prog Ser 329: 13-21

Lehtimäki J (2000) Characterisation of cyanobacterial strains originating from the Baltic Sea with emphasis on Nodularia and its toxin, Nodularin. PhD dissertation, University of Helsinki, Finland

Lewitus AJ, Holland AF (2003) Initial results from a multiinstitutional collaboration to monitor harmful algal blooms in South Carolina. Environ Monit Assess 81:361-371

> Lewitus AJ, Schmidt LB, Mason LJ, Kempton JW and others (2003) Harmful algal blooms in South Carolina residential and golf course ponds. Popul Environ 24:387-413

Lewitus AJ, Hayes KC, Kempton JW, Mason LJ, Wilde SB, Williams BJ, Wolney JL (2004) Prevalence of raphidophyte blooms in South Carolina brackish ponds associated with housing and golf courses. In: Steidinger KA, Landsberg JH, Tomas CR, Vargo GA (eds) Harmful Algae 2002. Florida Fish and Wildlife Conservation Commission, Florida Institute of Oceanography, and the Intergovernmental Oceanographic Commission of UNESCO, St. Petersburg, FL, p 350-352

> Lewitus AJ, White DL, Tymowski RG, Geesey ME, Hymel SN, Noble PA (2005) Adapting the CHEMTAX method for assessing phytoplankton taxonomic composition in Southeastern US estuaries. Estuaries 28:160-172 
Lewitus AJ, Brock LM, Burke MK, DeMattio KA, Wilde SB (2008) Lagoonal stormwater detention ponds as promoters of harmful algal blooms and eutrophication along the South Carolina coast. Harmful Algae 8:60-65

Mackey DJ, Higgins HW, Mackey MD, Wright SW (1997) CHEMTAX user's manual: a program for estimating class abundances from chemical markers-application to HPLC measurements of phytoplankton pigments. CSIRO Marine Laboratory, Hobart

Mallin MA, Wheeler TL (2000) Nutrient and fecal coliform discharge from coastal North Carolina golf courses. J Environ Qual 29:979-986

Mallin MA, Parsons DC, Johnson VL, McIver MR, CoVan HA (2004) Nutrient limitation and algal blooms in urbanizing tidal creeks. J Exp Mar Biol Ecol 298:211-231

Matthews E (1994) Nitrogenous fertilizers: global distribution of consumption and associated emissions of nitrous oxide and ammonia. Global Biogeochem Cycles 8:411-439

Millennium Ecosystem Assessment (2005) Ecosystems and human well-being: current state and trends, Vol 1. Island Press, Washington, DC

Millie DF, Schofield OM, Kirkpatrick GJ, Johnsen G, Tester PA, Vinyard BT (1993) Detection of harmful algal blooms using photopigments and absorption signatures: a case study of the Florida red tide dinoflagellate, Gymnodinium breve. Limnol Oceanogr 42:1240-1251

Moisander PH, Ochiai M, Lincoff A (2009) Nutrient limitation of Microcystis aeruginosa in northern California Klamath River reservoirs. Harmful Algae 8:889-897

Nixon SW (1995) Coastal marine eutrophication: a definition, social causes and future concerns. Ophelia 41:199-219

Nosengo N (2003) Fertilized to death. Nature 425:894-895

Ohmori M, Ohmori K, Strotmann H (1977) Inhibition of nitrate uptake by ammonia in a blue-green alga, Anabaena cylindrica. Arch Microbiol 114:225-229

Oliver RL, Ganf GG (2000) Freshwater blooms. In: Whitton BA, Potts M (eds) The ecology of cyanobacteria-their diversity in time and space. Kluwer Academic, Dordrecht, p 149-194

Paerl HW (1997) Coastal eutrophication and harmful algal blooms: importance of atmospheric deposition and groundwater as 'new' nitrogen and other nutrient sources. Limnol Oceanogr 42:1154-1165

Pinckney JL, Millie DF, Howe KE, Paerl HW, Hurley JP (1996) Flow scintillation counting of ${ }^{14} \mathrm{C}$-labeled microalgal photosynthetic pigments. J Plankton Res 18:1867-1880

Pinckney JL, Richardson TL, Millie DF, Paerl HW (2001) Application of photopigment biomarkers for quantifying microalgal community composition and in situ growth rates. Org Geochem 32:585-595

Rapala J, Sivonen K, Lyra C, Niemelä SI (1997) Variation of microcystins, cyanobacterial hepatotoxins, in Anabaena spp. as a function of growth stimuli. Appl Environ Microbiol 64:2206-2212

Redfield AC, Ketchum BH, Richards FA (1963) The influence of organisms on the composition of seawater. In: Hill MN (ed) The sea, Vol 2. Interscience, New York, p 26-77

Richardson TL, Pinckney JL, Paerl HW (2001) Responses of estuarine phytoplankton communities to nitrogen form and mixing using microcosm bioassays. Estuaries 24: 828-839

Ryther JH, Dunstan WM (1971) Nitrogen, phosphorus and

Editorial responsibility: William Kemp,

Cambridge, Maryland, USA eutrophication in the coastal marine environment. Science 171:1008-1013

Sakamoto T, Bryant DA (2001) Requirement of nickel as an essential micronutrient for the utilization of urea in the marine cyanobacterium Synechococcus sp. PCC 7002. Microbes Environ 16:177-184

Shea N (2001) 1999-2000 Lake study report. Kiawah Island Community Association, Kiawah Island, SC

Sivonen K (1990) Effects of light, temperature, nitrate, orthophosphate, and bacteria on growth of hepatotoxin production by Oscillatoria agardhii strains. Appl Environ Microbiol 56:2658-2666

Smith VH (1983) Low nitrogen to phosphorus ratios favor dominance by blue-green algae in lake phytoplankton. Science 221:669-671

Sokal RR, Rohlf FJ (1981) Biometry: the principles and practice of statistics in biological research, 2nd edn. Freeman, San Francisco, CA

Solomon CM, Collier JL, Berg GM, Glibert PM (2010) Role of urea in microbial metabolism in aquatic systems: a biochemical and molecular review. Aquat Microb Ecol 59: $67-88$

Strosnider WH, Hitchcock DR, Burke MK, Lewitus AJ (2007) Predicting hydrology in wetlands designed for coastal stormwater management, no. 077084. American Society of Agricultural and Biological Engineers, St. Joesph, MI, p $1-17$

Tilman D, Kilham SS, Kilham P (1982) Phytoplankton community ecology: the role of limiting nutrients. Annu Rev Ecol Syst 13:349-372

Tilman D, Kiesling R, Sterner R, Kilham SS, Johnson FA (1986) Green, bluegreen and diatom algae: taxonomic differences in competitive ability for phosphorus, silicon and nitrogen. Arch Hydrobiol 106:473-485

Tufford DL, Samarghitan CL, McKellar HN, Porter DE, Hussey JR (2003) Impacts of urbanization on nutrient concentrations in small southeastern coastal streams. J Am Water Res Assoc 39:301-312

> Turpin DH, Layzell DB, Elrifi IR (1985) Modeling the C-economy of Anabaena flos-aquae: estimates of establishment, maintenance, and active costs associated with growth on $\mathrm{NH}_{3}, \mathrm{NO}_{3}{ }^{-}$, and $\mathrm{N}_{2}$. Plant Physiol 78:746-752

Utermöhl H (1958) Zur Vervollkommnung der quantitativen Phytoplankton-Methodik. Mitt Int Ver Theor Angew Limnol 9:1-38

van der Westhuizen AJ, Eloff JN (1985) Effect of temperature and light on the toxicity and growth of the blue-green alga Microcystis aeruginosa (UV-006). Planta 163:55-59

Vézie C, Rapala J, Vaitomaa J, Seitsonen J, Sivonen K (2002) Effect of nitrogen and phosphorus on growth of toxic and nontoxic Microcystis strains and on intracellular microcystin concentrations. Microb Ecol 43:443-454

Vincent WF (1992) The daily pattern of nitrogen uptake by phytoplankton in dynamic mixed layer environments. Hydrobiologia 238:37-52

Wright SW, Jeffrey SW (2006) Pigment markers for phytoplankton production. Handb Environ Chem 2N:71-104

Zimmerman CF, Keefe CW (1991) EPA Method 353.4, Determination of nitrate + nitrite in estuarine and coastal waters by automated colorimetric analysis. An internal manual of methods for the determination of nutrients in estuarine and coastal waters, Revision 1.1

Submitted: July 20, 2010; Accepted: May 4, 2011

Proofs received from author(s): July 18, 2011 